\title{
THE ROLE AND CHARACTERISTICS OF RURAL TOURISM IN SERBIA: CASE STUDY OF VOJVODINA REGION
}

\author{
Branislav Vlahović ${ }^{1}$ (D) \\ Dubravka Užar ${ }^{2}$ (D)
}

DOI: https://doi.org/10.31410/tmt.2019.475

\begin{abstract}
Serbia is a land of rural character and is one of the most agrarian countries in Europe. The rich natural, cultural and historical diversity of the Republic of Serbia creates exceptional conditions for the development of rural tourism, as well as the placement of the wide offer for different segments of demand in the tourist market. Understanding consumer behaviour in rural tourism is a necessary condition for the successful diversification of any rural socio-economic system. The aim of the research is to examine the attitudes and preferences of potential users of rural tourism services in the Republic of Serbia. It is important to identify tourist needs in order to create the best supply of rural tourism. Rural tourism provides a new and different experience that cannot be achieved at traditional mass tourism destinations. These results could provide useful insight for decision makers, in particular as regards local planning strategies.
\end{abstract}

Keywords: Rural Tourism, Agrotourism, Tourists, AP Vojvodina.

\section{INTRODUCTION}

Contemporary tendencies in the tourism market impose the need to continuously design, plan, shape and improve the tourism product. The definition of tourism, adopted by the International Association of Scientific Experts in Tourism (AIEST), reads: "Tourism is a set of relationships and phenomena that result from the visitors' travel and stay in a place, if that stay is not based on permanent residence and if no business is associated with such stay.'(Unković and Zečević, 2006). Tourism is currently one of the world's leading socio-economic phenomena and the fastest growing and transformative industry in the world. Today, tourism is one of the most propulsive social and economic activities in the world (Petković et al., 2011). It has certain peculiarities by which it differs from other economic activities, namely (Unković and Zečević, 2006):

- Heterogeneity of its structure,

- High degree of elasticity of demand for tourist services and inelasticity of supply,

- The seasonal character of the business is emphasized,

- Specific features regarding the nature of this activity.

The development of tourism as a highly labor-intensive activity can significantly increase employment and thus contribute to solving the unemployment problem, which is one of the burning problems of many economies today. In terms of the impact of tourism on employment, two types of employment are most commonly mentioned: direct and indirect employment. Direct employment refers to employment in activities that are directly related and dependent on tourism (for example, employment in hotels, restaurants, travel agencies, nightclubs, etc.). Indirect employment refers to employment in activities that are indirectly related to tourism and derive significant benefits from tourism (such as agriculture, construction, trade, gas stations, etc.). The development of tourism has an impact on both direct and indirect employment (Bošković, 2010).

\footnotetext{
1 University of Novi Sad, Faculty of Agriculture, Trg Dositeja Obradovića 8, 21000 Novi Sad, Serbia

2 University of Novi Sad, Faculty of Agriculture, Trg Dositeja Obradovića 8, 21000 Novi Sad, Serbia
} 
FAO (Food and Agriculture Organization of the UN) sees the development of tourism in rural areas as a direct agricultural interest, because it provides a market for its products, both inside and outside the farm, helping to reduce poverty among smallholder farmers and rural areas in general, and it also provides an additional source of income for the farm by adding value to the primary products, as well as by employing surplus labor and available space and facilities. Small family farms find it extremely difficult to survive in a market in which major players are large agricultural producers, and rural tourism is ideal to diversify their activities and ensure the sustainability of the farm. The development of tourism is an impetus for introducing improvement in the agricultural production, processing and supply of food, as well as introducing modern standards (including the promotion of high-quality food, actualization of safety issues). For tourism as an economic activity, agriculture and farming are not only a necessary source of food, but also a source of attractive activities and the creator of attractive surroundings, landscapes and biodiversity, which help to increase the diversity of tourist offer. Tourism, on the other hand, brightens the rural setting because the local community has the tangible material benefit of maintaining its attractive traditional appearance (Milovanović and Đorđević Milošević, 2012).

Serbia has great potentials for development of rural tourism. Rural regions are extremely rich in colourful flora and fauna, geothermal springs, healing mud, organic product production, and cultivation, as well as diverse folklore and cultural heritage. The rich natural, cultural and historical diversity of the Republic of Serbia creates exceptional conditions for the development of rural tourism, as well as the placement of the wide offer for different segments of demand in the tourist market (Đenadić, et.al, 2016). Tourism has been identified as the key sector which can drive the diversification of the rural economy and can support Serbia (Erdeji, et.al, 2013). Rural Tourism can play a key role in Serbia in terms of diversifying rural economy, thereby creating employment opportunities which will generate additional incomes for rural households and reduce unemployment. Along with rural areas tourism, development comes to actualization of significant export earnings, as throughout the food consumption in touristic objects, as well as throughout increased trade turnover, more intensive traffic, activation of cottage industry etc., and all in function to increase employment (Cvijanović et. al., 2007). Therefore, it is necessary to implement a sustainable rural tourism policy in the future to maximize the positive and minimize the negative effects (Gajić, 2010).

In order to utilize the full potential of rural tourism and to create a sustainable, competitive tourist product of rural tourism, it is necessary to conduct market survey and examine needs, motives and preferences of consumers. The aim of the research is to examine the attitudes and preferences of potential users of tourism services. The research should answer the questions: how much are potential users aware of rural tourism, what would be their main motives for using these services, which are the limiting factors when choosing a destination in rural areas, are there any specific activities which would particularly attract them, etc. Rural tourism providers can respect the needs and requirements of potential users in order to define and organize specific activities for them.

\section{CONCEPTUAL DETERMINANTS OF RURAL TOURISM}

The Council of Europe has defined rural tourism as a tourism that encompasses all the activities in the rural or village area, the most important features being the quiet environment and the absence of noise, a clean environment, communication with the hosts who introduce guests to the farm jobs and domestic food (Ružić, 2009). The Organization for Economic Co-operation and Development (OECD) has provided a definition of rural areas for the purpose of comparing rural conditions and trends, although there are wide variations in rural problems, views and 
policies at national level. At the municipal level, according to the OECD, rural areas are those with a population density of less than 150 inhabitants per $\mathrm{km}^{2}$. Rural area in Serbia is defined as an area whose main physical and geographical land use is the use of land for the production of agricultural and forestry products. According to this definition, approximately $70 \%$ of the territory of Serbia can be classified as rural area, where about $43 \%$ of the population lives. This data further underscores the importance of rural tourism as a business activity that would provide jobs for people who have decided to stay in their villages and preserve their heritage from oblivion (Rural Tourism Handbook, 2015).

Rural tourism is one of the priorities in the tourism development of many European countries. The rural tourism market is on the rise, while at the same time the future of many rural areas is uncertain, due to changes in agricultural production or the attractiveness of urban areas due to a higher standard of living (Swarbrooke, 1996).

One of the most comprehensive definitions of rural tourism has been given by the Pan-European Non-Governmental Organization (EuroTer), according to which rural tourism, within the tourism economy, is a "tourist valorization of agrarian areas, natural resources, cultural heritage, rural settlements, local traditional customs and products through specially designed tourism products that reflect the identity of the area and meet the needs of guests in terms of accommodation, food and drink, recreation and activities, animation and other services, with the aim of sustainable local development, but also by providing adequate responses to the needs of today's guest within the newly created relationships between the city and the village (rural area) "(Horwath Consulting Zagreb, 2009).

Rural tourism represents the broadest concept that covers all tourism products and services within a rural area. It is not necessarily a supplementary activity on the farm that generates additional income, but it can also be a professional activity. In addition to tourism on agricultural holdings, it also includes the areas in which they predominate: the natural environment, the rural environment, small settlements and villages, hamlets, segregated agricultural holdings with agriculture and forestry as the main economic branches (Žanko 2013).

Smith et al. (2010) provide the following definition of rural tourism: Rural tourism describes the forms of tourist activities that take place in rural areas and which include local culture, traditions and economic activities, outdoor activities, as well as the experiences that have been achieved in undisturbed rural ambience. The local community plays an important role in promoting rural tourism product.

Rural tourism in Serbia is defined as tourism that offers the visitor a „rural environment” by enabling him to experience in a unique way the web of life, nature, culture and people. This means that the visitor enjoys authentic, original experiences and a return to the roots or essence of the rural lifestyle. Rural tourism is based on the principles of sustainability and includes a range of activities and services organized by the population in rural areas on the basis of the elements that characterize those rural areas. The offer in rural tourism does not include only the visible characteristics of nature, architecture, folklore, gastronomy, but also the invisible ones, such as, for example, traditional hospitality, customs, culture of preserving nature, culture of communication, beliefs and legends of local people of different nationalities and religions who have developed a specific way of life in a particular area. It is this experience of a unique multidimensional network of life realized through personal contact with the local population 
that makes rural tourism unique. The importance of rural tourism stems from the interaction of agricultural production, manufacture of traditional products, the presentation of tradition, local and traditional food and tourist services.

The problem of defining rural tourism has become even more difficult, because very often in the professional literature, the term rural tourism is identified with the term agrotourism. Sirgy (2001) considers that agrotourism is only a part of the segmentation of rural tourism (in addition to hunting, eco, health, cultural, wine, gastronomic and others).

Agrotourism is a form of rural tourism that involves tourists staying in a rural environment, which provides opportunities for active participation in the life and work of the rural estate. Tourists can take part in fruit and vegetable harvesting, horseback riding, learning about wine, buying farm souvenirs and the like. Agrotourism is becoming an increasingly important sector of tourism, as people are increasingly interested in how, where and who produces food. Agrotourism is a type of tourist rural family business where the main activity is agricultural production, while tourist accommodation and catering services are an additional activity. In addition to basic catering and lodging services, other tourist services (activities, service packages) can be organized on the farm, which aim to provide guests with an opportunity for an active vacation, or to maximize the use of tourism potential of the estate. The owner of the estate, as a rule, lives on the farm itself with his family, while the tourist services use excess space within the estate. Therefore, the guest, in constant and direct interaction with the host and his family during the visit to the estate and first-hand has the opportunity to get acquainted with customs, tradition, the way and culture of life, cultural micro-world, traditional agricultural production, typical products and local gastronomy (Baćac, 2011). Like any other form of tourism, agrotourism has important elements that make it different and special, distinctive and attractive to tourists. The key elements of agrotourism are the following (Jelinčić, 2007):

- Located in rural areas,

- Functionally rural: based on small entrepreneurship, outdoors in direct contact with nature, based on heritage and traditional rural activities,

- Allows participation in the activities, traditions and lifestyle of the local population,

- Provides personalized contact,

- Settlements and buildings are rural (small scale),

- Traditional in meaning, growing slowly and organically, associated with local families,

- Different types, a complex sample of rural environment, economy, history and localities,

- High share of tourist revenue that benefits the local community, etc.

Rural tourism is a complex type of tourism because it is composed of different types of tourism that occur in rural areas, and from the aspect of tourist offer or product, the following forms stand out (Demonja, Ružić, 2010; Todorović, Štetić, 2009 ): ecotourism, cultural tourism, hunting and fishing tourism, sport and recreation tourism, adventure, camping tourism, gastronomic tourism, wine tourism, health tourism, cultural tourism, religious tourism, educative tourism, nautical tourism, residential tourism, etc. Among the types and shapes of rural tourism, tourism on agricultural estate is the most prominent.

From the above, it is evident that tourism is a complex phenomenon that is not easy to define, nor is there a unique definition of a tourism product. The tourism product is a result of the work and effort of the tourist offer on the one hand, and on the other is the result of the current un- 
derstanding, wishes and needs of tourist users (Senečić, Grgona 2006). The tourism product is composed of several components (Midlton and Clarke, 1993):

- Attractions of the tourist area because tourists are attracted by events related to a certain area, such as cultural, sports, health or other events or some of the natural characteristics of the area,

- Products and services offered by a specific tourist area, such as entertainment, recreation and the like, which are complementary to meeting the tourist needs,

- The accessibility of the tourist area, which represents the spatial distance from the permanent residence of the tourist and the time spent to overcome this spatial distance.

The entities involved in rural tourism are firstly the farm, and then the village collectives and associations, local self-government, tourism organizations and agencies, as well as the competent ministries. All the above-mentioned entities should work together to promote rural tourism and thereby promote all the benefits of doing so. The most important factor in rural tourism is accommodation services with additional local facilities (Gašić and Ivanović, 2018). Within the framework of rural tourism, agrotourism (farm holidays), nature tourism (nature tourism), green tourism, special interests (gastronomy and wine, observation of plant and animal life), active holidays (horseback riding, biking, trekking, etc.), and historical and cultural forms of tourism are emphasized.

The Autonomous Province of Vojvodina is a relevant research area as the largest part of its territory (about 90\%) is rural. Vojvodina has a great opportunity for the development of rural tourism, first of all, because of its favorable geographical position, developed agriculture, which forms the basis for the development of this type of tourism. The development of rural tourism in this climate would eventually halt the departure of young people from the countryside and create conditions for increasing employment, since tourism is an area in which human labor is very important, because it requires a large amount of personal services, and there is also the possibility of restoring and reusing abandoned homes with an authentic look.

A wide variety of destinations are available to rural tourism service users. Every tourist country today strives for branding its own tourist destination, creating a pre-recognizable image and creating the distinctive identity of a desirable tourist country. In order to position a destination, the unique features of a destination, often intertwined with traditional ones, are often emphasized in order to preserve originality. When it comes to destinations, users are looking for destinations that are not subject to the commercialization of mass tourism, but rather those that have retained authenticity. Agrotourism opens the possibility of branding a destination by highlighting and using a community identity, whereby authenticity adapted to contemporary trends should be the criterion for ranking tourist holdings instead of marginalizing and shutting down family farms. Urbanization, modernization, technology development, industrialization and accelerated pace of life have led to changes in attitudes and preferences of users of tourism services (Žanko, 2013).

Successful rural tourism development requires not only attractive resources, capacities and quality products, but also efficient organization and marketing. In many European Union countries, rural tourism strategies are also included in regional and rural development strategies, which help to retain population in the city, create jobs, and ultimately contribute to the socio-economic progress of the areas falling behind (Muhi, 2013). 


\section{DATA SOURCES AND METHODOLOGY OF WORK}

Primary data on the facts, opinions and behaviors of potential users of rural tourism services were used. Used method was poll research survey, based on previously made questionnaire, done on simple random sample of 150 respondents within the area of Novi Sad during the period August-September 2019. Although the number of respondents does not mean full representativeness of the sample, the results obtained are quite indicative to point to certain regularities in the views of users of rural tourism services. The questionnaire used a combination of closed-ended questions with a choice of prompt answers and open-ended questions where no answer was offered but respondents gave their own answers. The sample selected has the characteristics of a suitable sample because the respondents were selected in the sample with due regard for their availability. Care was taken to ensure that respondents were different in terms of age structure, place of residence, education, employment status and income, in order to obtain results that can well reflect the entire basic set by using the inferential statistics. Descriptive statistical analysis was used in the paper. The historical-logical method was used in the study of the overall material, with special reference to the development of rural tourism in Serbia. This paper is part of a broader study conducted at the Faculty of Agriculture in Novi Sad. The results of the research should provide destinations for rural tourism, an idea of which direction they should take their further development in, and what they need to become successful destinations of rural tourism.

\section{FUTURE RESEARCH DIRECTIONS}

A slightly larger number of male respondents were surveyed, at $56 \%$ compared to $44 \%$ of female respondents. Most respondents (25\%) are under 25 years of age. Regarding the level of education of the respondents, most have completed high school (almost half), while $40.0 \%$ have a college diploma (Table 1).

Table 1: Social and demographical characteristics of the respondents

\begin{tabular}{|c|c|c|c|}
\hline & able & Frequency & Percentage (\%) \\
\hline Condor & Male & 84 & 56,0 \\
\hline Gender & Female & 66 & 44,0 \\
\hline & up to 25 years old & 35 & 25,0 \\
\hline & from 26 to 35 years old & 32 & 21,0 \\
\hline Age group & from 36 to 45 years old & 24 & 16,0 \\
\hline & from 46 to 55 years old & 28 & 19,0 \\
\hline & over 55 years old & 28 & 19,0 \\
\hline & Elementary school & 1 & 0,7 \\
\hline Education & High school & 69 & 46,0 \\
\hline Equeation & Faculty & 60 & 40,0 \\
\hline & Postgraduate studies & 20 & 13,3 \\
\hline
\end{tabular}

Source: calculations of the authors

Familiarity with the concept of rural tourism - when asked if they are familiar with the term rural tourism, more than half of the respondents (56\%) answered affirmative, $40 \%$ of the respondents were partially familiar with the term (they couldn't define it accurately), while $4 \%$ of respondents were absolutely unfamiliar with the term (Figure 1). The results obtained indicate a good knowledge of the respondents regarding the concept of rural tourism. This is an essential prerequisite for the development of this type of tourism in Vojvodina. There is a statistically significant difference in the answers with respect to the amount of income of the respondent. Higher-income respondents were better acquainted with the concept of rural tourism, rather than lower-income respondents. 


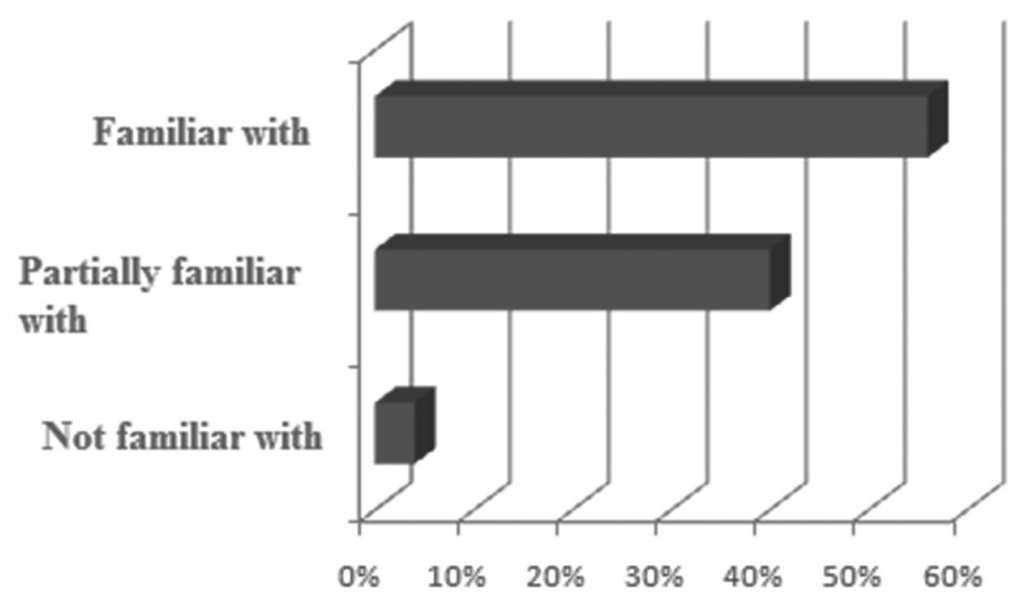

Figure 1: Familiarity with the concept of "rural tourism" (\%)

Source: calculations of the authors

Motives for the use of rural tourism services - this question was raised in order to identify the motives most important for the respondents for using the rural tourism services. Motivation regards to consumer incentives, under the influence of certain external and internal factors, in the process of purchasing products and services (Vlahović et.al, 2012). Internal factors are the personal needs and emotions of the individual, while external motives are the result of the action of external influence (Vlahović \& Užar, 2017). This is the mental state of the person or the invisible inner power that organizes human energy and directs it towards a specific goal (Maričić, 2011).

The motives that attract tourists to rural areas are a reflection of the growing interest in outdoor recreation, as well as many other general trends in tourist motivation. „The appeal of rural areas to tourism and relaxation can best be explained by the image of the rural, which is closely linked to the traditional and romantic idea of the" good old days", an innocent and one-of-a-kind lifestyle, intact nature and the perfect adaptation of man to his natural environment. Thus, the longing and need for returning to the roots and a simple lifestyle without a highly organized, stressful and urban environment leads to an increasing interest in rural areas" (Kastenholz, et al. 1999).

Halloran (2000) states that the main motives for practicing rural tourism in Australia are visiting friends and relatives, visiting an interesting rural area, outdoor activities, outdoor activities, recreation, consuming of the traditional and autochthonous rural products, learning about the traditional lifestyle, etc. The motives can be very different: escape from the domicile of everyday life, but also from modern and noisy tourist destinations, the search for new, idyllic surroundings, beautiful landscapes, preserved nature, more moderate climate, simple way of living (return to the roots), possibility of socialization with ,ordinary people”, desire for individually approaching the guest by the host, enjoying a relaxing environment, „healthy” food, clean air, water (Kesar, 2013). On the other hand, there are also tourists who, for various reasons, are not interested in rural tourism, especially in agrotourism. They usually have a negative mental image of village space, as insufficiently civilized, too isolated, ,muddy', or generally uncomfortable environment (Rabotić, 2012).

The answers obtained imply that there are many different motives that have led the respondents to use rural tourism services and that, by combining these motives in the supply of rural tourism, great satisfaction of the users of these services could be achieved. Table 2 shows the average values of the answers received about the respondents' motives. 
Table 2: Motives for using rural tourism services

\begin{tabular}{|l|c|c|}
\hline Motives & Mean value & St. dev \\
\hline A break from the city lifestyle & 12,3 & 7,9 \\
\hline Enjoying the specialties of the local area & 10,2 & 6,8 \\
\hline Participation in the estate activities & 4,2 & 3,2 \\
\hline Getting to know the local culture & 7,7 & 6,1 \\
\hline Conservation of nature and environment & 7,2 & 5,2 \\
\hline Hunting and fishing & 2,7 & 1,8 \\
\hline Learning about the local lifestyle & 5,0 & 3,2 \\
\hline
\end{tabular}

Source: calculations of the authors

Research findings show that ,a break from the city lifestyle” (12.3), ,enjoying the specialties of the local area" (10.2), ,getting to know the local culture” (7.7), ,preserving nature and environment (7.2)" are the most important motives for the participation of respondents in rural tourism. On the other hand, the lowest scores were found on motives related to "learning about the local lifestyle" (5,0), "participating in traditional farm activities" $(4,2)$ and "hunting and fishing" $(2,7)$, indicating that they represent secondary motives for the decision to use rural tourism (Table 2).

Based on the conducted testing on the difference in motivation, it was confirmed that there is a statistically significant difference in the respondents' motivation for using rural tourism services in Vojvodina regarding the respondents' income. Higher-income respondents are more interested in using rural tourism services than lower-income respondents.

Time of using rural tourism services - in order to see the time users are willing to spend on their holidays in rural areas, the largest number of respondents (57\%) are ready to take the weekend to use rural tourism services (Figure 2). 13\% of respondents indicated a one-day-stay with overnight included, $11 \%$ of respondents were prepared to spend one day in a rural setting. $6 \%$ of respondents are ready to spend less than one day (lunch or dinner only). A total of $13 \%$ of respondents are ready to spend more days in a rural environment using rural tourism services.

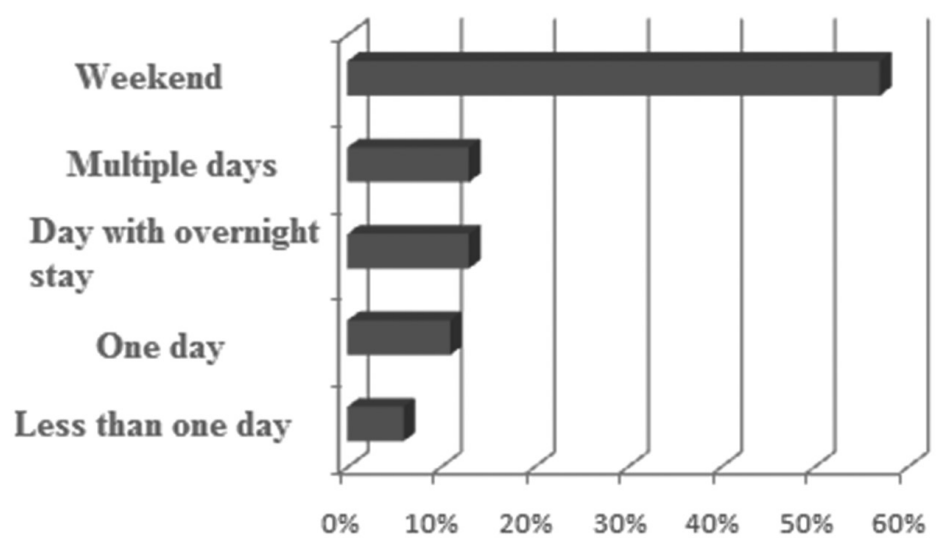

Figure 2: The time users are willing to spend on rural tourism

Source: calculations of the authors

The conclusion is that tourists are not prepared to spend too many days using rural tourism services. Indeed, this is the reason why rural tourism service providers have to devise adequate services that would entice tourists to use rural tourism services for several days. There is a statistically significant difference in the time of the use of rural tourism services, given the amount 
of income of the respondents. Higher-income respondents were more interested in longer-term use of rural tourism services, compared to lower-income residents.

The answers received underline the fact that, for a successful rural tourism offer, it is necessary to have accommodation capacities, since the majority of respondents stated answers that mean at least one overnight stay in rural destinations.

The possibility of meeting tourism needs is directly related to the volume and structure of financial resources (Vlahović, et. al., 2015). Regarding the amount of funds that respondents of rural tourism services are ready to spend for this purpose, the following results were obtained:

- Respondents who wish to use food services (lunch or dinner) are prepared to pay an average of 3,080 dinars. The minimum is RSD 2,000 and the largest is RSD 5,000;

- Respondents who intend to spend one day in rural areas are on average willing to spend 5,090 dinars for this purpose. The minimum is RSD 2,000 and the maximum is RSD 10,000 ;

- Respondents who want to spend day and night in rural tourism facilities are prepared to spend an average of 6,780 dinars. The minimum amount that users are willing to spend is 3,000 dinars, while the largest amount is 15,000 dinars;

- When it comes to weekend, the most cited period as the time they would spend in rural areas, the average amount they are willing to spend is 8,900 dinars. The minimum amount is RSD 5,000 and the maximum is RSD 20,000;

- Respondents who pointed out that they would like to spend more days using rural tourism services are willing to spend an average of 18,150 dinars (Table 3). The minimum amount stated is RSD 7,000 and the maximum amount is RSD 30,000.

Table 3: Allocation of funds for visit a rural destination and use rural tourism services

\begin{tabular}{|l|c|}
\hline Duration of the stay & Average amount (RSD) \\
\hline Visiting for lunch or dinner & 3.080 \\
\hline 1 day & 5.090 \\
\hline day with overnight stay & 6.780 \\
\hline Weekend & 8.900 \\
\hline Multiple days & 18.150 \\
\hline
\end{tabular}

Source: calculations of the authors

There is a significant statistical difference between the amount of respondents' income and the funds determined for spending. Respondents with higher incomes are ready to allocate more funds for the more appropriate rural tourism facilities.

Users of rural tourism services - they can be families with children, married couples without children, young people, pensioners, individual tourists or organized tourist groups. Analyzing the answers received regarding with who the respondents would use the rural tourism services, it is observed that the majority of respondents (44\%) would spend their holidays in rural areas with their families. At the same time, $28 \%$ of respondents would engage in rural tourism activities with a partner, while $25 \%$ of respondents prefer to visit a rural destination within an organized group. $3 \%$ of the respondents would practice this type of tourism (Table 4) by themselves. There is no statistically significant difference between the answers received and the amount of respondents' income.

Bramwell (1994) defines rural tourism destinations as broader areas with natural environments, where there are special natural, economic and socio-cultural features, such as tradition, local 
cooperation, trust and good interrelationships, and, as such, create a special tourism product that is primarily based on a small-scale economy, is friendly to the environment, „,coloured” by ethnic elements, in a word, ,sustainable.”

Table 4: Who would you use rural tourism services with

\begin{tabular}{|l|c|c|}
\hline With & Frequency & percentage (\%) \\
\hline Alone & 4 & 3,0 \\
\hline With a partner & 42 & 28,0 \\
\hline With family & 66 & 44,0 \\
\hline Organized group visit & 38 & 25,0 \\
\hline Total & 150 & 100,0 \\
\hline
\end{tabular}

Source: calculations of the authors

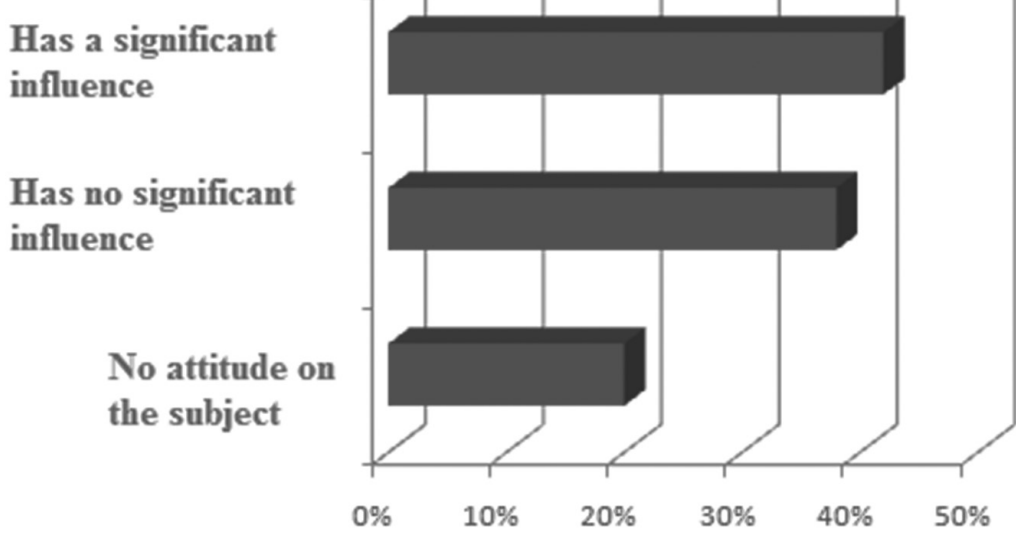

Figure 3: Influence of the distance on rural tourism (\%)

Source: calculations of the authors

Distance of destinations for the use of rural tourism services - in order to determine the influence of the distance of a particular rural destination on the decision on visit, it was concluded that for more respondents $(42 \%)$ the distance plays a significant role in choosing a rural vacation. At the same time, $38 \%$ of respondents believe that distance does not represent a significant factor when choosing a destination. $20 \%$ of respondents do not have a clearly defined attitude on this issue (Figure 3).

The answers obtained show that the users of tourist services are still not very willing to travel longer distances to spend their holidays in rural areas. There is no statistically significant difference between the answers received and the amount of respondents' income.

Tourism events related to rural tourism - the question was asked to consider the number and significance of rural tourism events, as well as what are the most famous ones. It can be concluded that more than half of the respondents $(55 \%)$ believe that there are enough events in Vojvodina that have a point of contact with rural tourism, but that there may be more. $19 \%$ of respondents stated that there are a sufficient number of events in Vojvodina, while $16 \%$ of respondents think that there are not enough events related to rural tourism. At the same time, $10 \%$ of respondents do not have a defined attitude on this issue (Figure 4).

Vojvodina is an area where different cultures intersect, resulting in many different customs and traditions that are attractive to visitors, so it is not surprising that a large number of respondents are familiar with various tourist manifestations in Vojvodina. Certainly, a larger number 
of events are required that would be fully devoted to rural tourism and its promotion, since a large number of existing events, although related to rural tourism, are not attractive enough to hold tourists for more than a day. Analyzing the answers received regarding the events that are associated with rural tourism, it is noted that the largest number of respondents $(19.17 \%)$ cited the manifestation „Kobasicijada” in Turija, which is absolutely associated with rural tourism, followed by „Kupusijada” in Futog with $8.22 \%$ of respondents. Events the least related to rural tourism are the "Pasuljijada" in Temerin and the "Pudarski dani" in Irig. Respondents mentioned other manifestations as: „Tucanijada” in Mokrin, „Grape harvesting days” in Vršac, „Čvarak fest” in Kać, „Pile fest” in Žitište, „Mundijada” in Šajkaš, „Gander fights” in Mokrin, „Pihtijada” in Rumenka, „Grape Days” in Banoštor, „Dužijanca” in Subotica, „Brandy Fest” in Kovilj, „Štrudlijada” in Dolovo,” Fijakerijada” in Crepaja and „Kulenijada” in Bački Petrovac, etc. There is no statistically significant difference between the responses received and the amount of respondents' income.

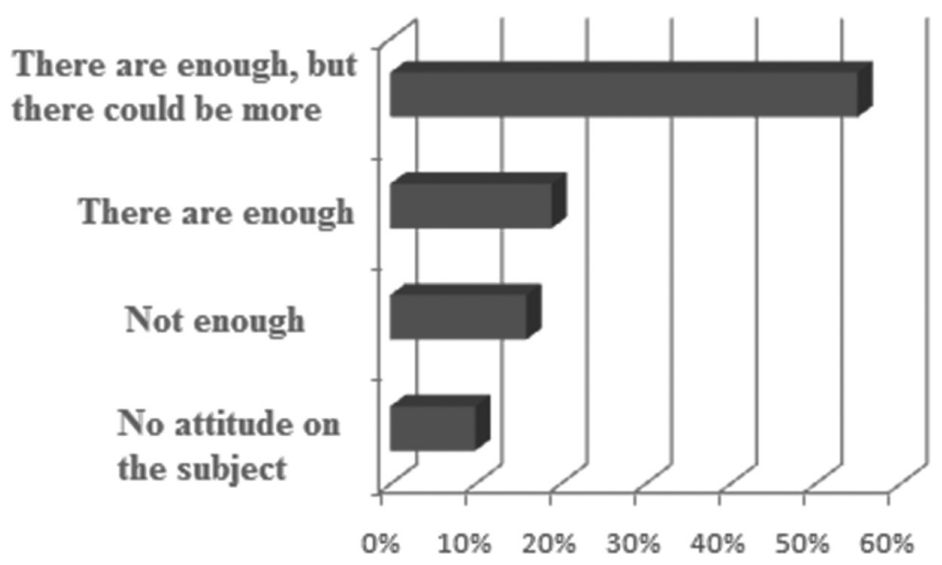

Figure 4: Events tied to rural tourism (\%)

Source: calculations of the authors

Such a large number of events that respondents recognize and associate with rural tourism is very encouraging. They attract a large number of visitors from local places, as well as from the surrounding and foreign countries. Since some of these events last for several days, it is necessary to offer the accommodation services, as well as the accompanying activities that will animate them. Events should be tailored to the needs and requirements of tourists.

The role of gastronomy in rural tourism - the question was asked in order to obtain information on the role and importance of gastronomy in rural tourism. Almost half of the respondents $(47 \%)$ believe that gastronomy is a major factor in rural tourism in Vojvodina, while at the same time $36 \%$ of interviewees gave the opposite answer. $10 \%$ of respondents stated that they did not know whether gastronomy was a major factor in Vojvodina's rural tourism, while 7\% of respondents did not have a defined attitude on this issue (Figure 5).

Certainly, a multitude of different traditional dishes and drinks is one of the major assets of the rural tourism of Vojvodina. Consuming local and autochthonous food and beverages is an essential element of rural tourism. Based on the answers received, the gastronomic offer should be further developed, e.g. by involving the visitors themselves in the process of making meals. At the same time, much more needs to be done to organize accompanying activities and achieving diversity that would further complement the rural tourism. There is no statistically significant difference between the answers received and the number of respondents' income. 
Participation of rural tourists in farm activities - the question was raised as to whether tourists are willing to directly participate in farm activities within rural tourism. From the location point of view, all activities of tourists in rural tourism can be divided into activities within the household, created by hosts, and activities outside the household within the rural destination, which can be created by hosts and other households, various associations, local tourism organizations, etc.

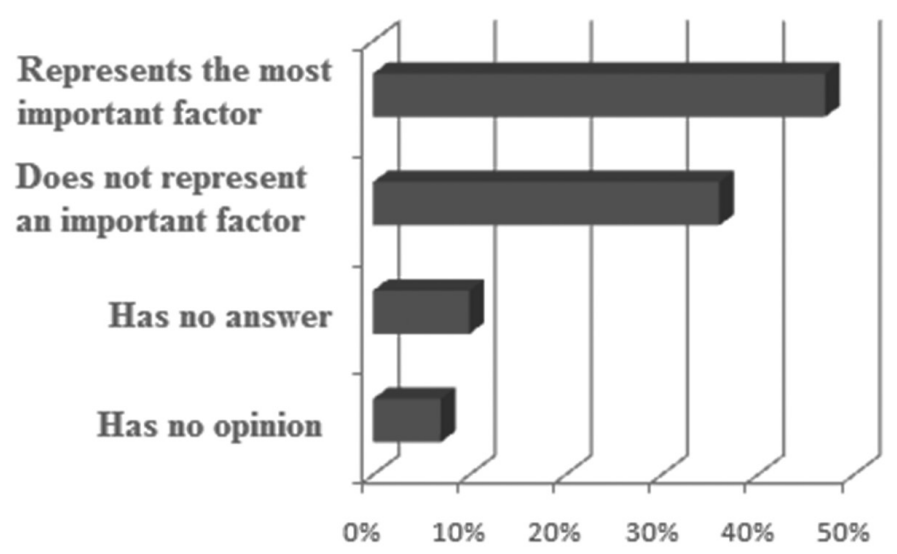

Figure 5: Significance of gastronomy in rural tourism (\%)

Source: calculations of the authors

Activities of tourists in rural households: that could be agricultural activities, food preparation - gastronomic activities and crafts. Agricultural activities: the villages are attractive in all four seasons (though at least in winter) and these climatic characteristics should be used as an advantage for rural tourism. In our country, mostly households are combined - their priority is agriculture, and tourism is a secondary activity, although in some households it grows into a primary activity. The villagers are engaged in crop production, fruit growing, livestock breeding, cultivating land and the like, and the offer should be tailored to the day-to-day life in the countryside without disturbing the steady flow of rural activities. The village should certainly retain its autochthonous and traditional way of agriculture and this is exactly what the village's tourism offer should be based on. Guests can be given the opportunity to take an active part in rural agriculture - picking raspberries, blackberries, cherries, harvesting corn, collecting hay, etc., working in the fields or on the farm, mowing grass, watching and, if they wish, participating in milking cows, making cheese and milk, preparing jam, which they could, with some compensation for the housewife, take home. They could help the hosts, learn many useful jobs, old crafts, traditionally prepare meals, attend the scene of making brandy next to a cauldron, or make homemade wine and the like. The traditional method of production (e.g. organic gardening) is becoming less and less enjoyable in the countryside, but it should be revived because it is the basis of „Green Tourism”. Food preparation: The advantage of the rural environment is the clean and unpolluted nature, which enables the production of organic and "healthy" food. Efforts should be made for households to produce food for the needs of tourists. Housewives nurture traditional food preparation. They could organize education in the preparation of gastronomic specialties of local cuisine, which are less and less on the table. Pies (e.g., buckwheat pie, cabbage pie, pumpkin pie, cheese pie...), gibanica, cicvara, proja, homemade bread, special dishes and roasted goods. Fostering homemade cuisine creates a unique ambience of intimacy and welcome. Handicrafts: Part of the national heritage is also homework and crafts, especially artistic, souvenir making, folk costumes and folklore. In addition to the basic accommodation offer, additional facilities should be designed to keep guests occupied, generating additional profits and positive economic effects. More and more guests who want to actively spend their holidays, learn something, discover, find out. 
Activities of tourists outside the household - tourists are no longer just peaceful observers (although this group is also numerous), but active participants in everyday activities. It is no longer enough just to see the destination, that is made possible by the internet, it is necessary to experience the destination. Tourists are "hungry" for new experiences, and experiences are created by activities in the destination. The activities of tourists outside the household and within the destination are predetermined, first of all, by the type of attractive motives to which they are attached, i.e. whether they are natural or anthropogenic (cultural) motives. All non-household activities can be classified into two groups: recreational and cultural activities (https://www.turizamiputovanja.com). In order to consider the views on whether users of rural tourism services would participate in activities that depict traditional life in rural areas, the following results were obtained: the majority of respondents (69\%) would participate in the aforementioned rural activities. At the same time, $17 \%$ of respondents are not entirely sure if they would participate in these activities, while $14 \%$ do not want to practice traditional activities when vacationing in rural areas. One percent of respondents do not have an opinion on this issue (Table 5). Households should monitor tourists' needs and define appropriate activities that tourists would like to enjoy. There is no significant statistical difference between the potential activities in the surrounding areas and the amount of respondents' income.

Table 5: Participation in activities in rural tourism (\%)

\begin{tabular}{|l|c|c|}
\hline Answer & Frequency & Percentage (\%) \\
\hline Would participate & 104 & 69 \\
\hline Maybe/not sure & 23 & 17 \\
\hline Would not & 21 & 14 \\
\hline Undecided & 2 & 1 \\
\hline Total: & 150 & 100 \\
\hline
\end{tabular}

Source: calculations of the authors

When carrying out tourism activities, respondents require that their vacations be accompanied by certain content that will contribute to their more enjoyable stay at the chosen destination. The answers to this question imply the conclusion that anyone who wants to engage in rural tourism must allow visitors to participate in their daily lives, to learn about their culture and way of life. At the same time, it is necessary to allow for the full atmosphere in order to completely relax and forget about their all-day obligations from the place of their permanent residence. Specifically for the tourism product, it is an effort to provide the visitor with personal contact, empathy for the environment in rural areas and as much as possible, give them the opportunity to participate in the activities, traditions and lifestyles of the local population (Rabotić, 2012).

Organizing additional activities in rural tourism - in order to consider the importance of organizing additional activities that would complement the stay in rural areas, the obtained results indicate that the largest number of respondents $(60 \%)$ consider it is important that during the stay in the rural areas, various kinds of additional activities (hunting, fishing, hiking, horseback riding, etc.) need to be organized in order to satisfy the subtle needs of tourists. At the same time, $25 \%$ of respondents think that organizing these activities is not necessary, so they answered „maybe" to this question, while $15 \%$ of respondents said that there was no need at all to carefully organize these types of activities during their stay in rural areas (Table 6). There is no significant statistical difference between additional activities in rural areas and the level of income of respondents. 
Table 6: Additional activities organized in rural tourism

\begin{tabular}{|l|c|c|}
\hline Answer & Frequency & Percentage (\%) \\
\hline Important & 90 & 60 \\
\hline Not necessary & 37 & 25 \\
\hline No need at all & 23 & 15 \\
\hline Total: & 150 & 100 \\
\hline
\end{tabular}

Source: calculations of the authors

Obtained results indicate that it is necessary to enable visitors to engage in such activities in order to complete the offer and to better meet the needs and wishes of tourists. For a quality and active holiday in this type of tourism, the rural ambience has a great role, which, due to its natural landscape, tradition and cultural content, attracts an increasing number of visitors. Rural tourism encourages the improvement of the quality of agricultural holdings and agricultural production, thus increasing economic activity and household businesses doing better. The reason is that the farms engaged in rural tourism offer the consumption and sale of fruits, vegetables, wine, brandy, culinary and other products that are produced or grown on the farm (Demonja and Ružić, 2010).

The connection between the consumption of food produced in the system of organic agriculture and rural tourism - when asked, the largest number of citizens, $71 \%$, answered that they would like to try the food produced in the organic agriculture system while staying in a rural area. At the same time, $18 \%$ answered that they might like to try, while $11 \%$ of respondents would not like to consume the food produced in this way (Table 7). A significant statistical difference can be observed between the income level of the respondents and the willingness to consume the food produced in the organic production system. Respondents with higher incomes are more ready to consume such food produced, compared to respondents with lower incomes.

Table 7: Readiness to consume food produced in organic production systems in rural tourism

\begin{tabular}{|l|c|c|}
\hline Answer & Frequency & Percentage (\%) \\
\hline Ready & 107 & 71 \\
\hline Maybe/not sure & 27 & 18 \\
\hline Not ready & 16 & 11 \\
\hline Total: & 150 & 100 \\
\hline
\end{tabular}

Source: calculations of the authors

This attitude is important from the point of view of the tourist service providers, in order to start their organic production or to buy such food that would be offered to tourists in the rural tourism. This can be a comparative advantage of the household, especially important for foreign tourists, who have higher incomes but also very specific requirements regarding the taste of food. When it comes to food that is produced in the organic production system, it is possible to provide some form of education for the interested guests on how that food is produced, which are the main goals of this type of production and what is its advantage over conventional food, etc.

Frequency of rural tourism promotional activities - the question was raised in order to review the frequency of promotional activities related to rural tourism in Vojvodina. The promotion of rural tourism is extremely important in order to influence the decision of potential tourists to visit these destinations. The majority of respondents (69\%) believe that promotional activities for rural tourism are under-implemented. At the same time, $18 \%$ of respondents think that they are sufficiently implemented, $9 \%$ of respondents think that they are not implemented at all (did not see any promotional activities for rural tourism), while $4 \%$ of respondents have no clear at- 
titude on this issue (Figure 6). There is no significant statistical difference between the answers received and the amount of income of the respondents.

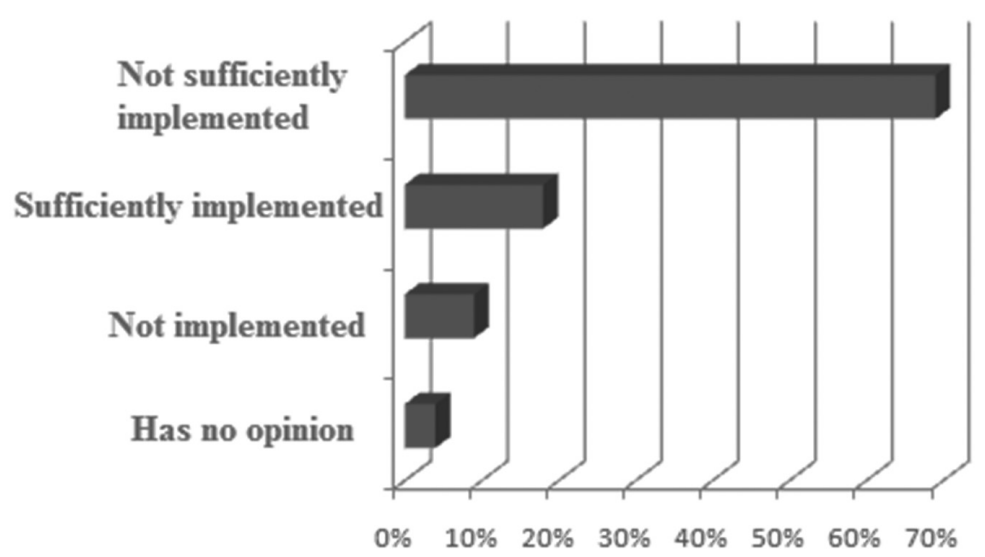

Figure 6: Percentage of rural tourism promotion activities in Vojvodina (\%)

Source: calculations of the authors

The answers received indicate that more effort and energy needs to be invested in rural tourism promotion activities (fairs, etc.). Greater assistance from local governments is also needed, and the relevant ministry and the APV Government need to be involved in this activity. Also, in order to bring tourists, farms must independently use different types of promotions (economic propaganda, sales promotion, publicity and public relations, etc.) and thus attract guests. Lately, social networking and the internet have been an effective way of providing low-cost sources of communication.

\section{CONCLUSION}

There are strong opportunities for the development of Rural Tourism in Serbia. Rural tourism is important to users because it provides a new and different experience that cannot be achieved at traditional mass tourism destinations. In Serbia, there is an opportunity to define a truly experience which is holistic and integrates these different components, thereby, creating a competitive positioning for Serbia. The key contribution of this paper is an insight into consumer behavior in rural tourism. It is important to identify tourist needs in order to create the best supply of rural tourism. In order to improve this knowledge, the present study seems to provide useful information through the analysis of attributes determining choice from the consumers' perspective for the selection of rural tourism sites, as part of the rural development planning process.

These results could provide useful insight for decision makers, in particular as regards local planning strategies. Decision makers must take steps in regulating the strategic goals in rural area such as self-employment and motivating young people to stay in the countryside, developing an overall offer for a tourist destination, raising the quality of accommodation for hospitality and tourism services, encouraging the production of organic food and local products as well as their placement through tourism and educating the employees in rural tourism. In order to achieve greater effects, it is necessary that the marketing and management of tourist destinations become significant in practical implementation at all levels from local, regional to national. In this way, the basis for achieving positive results is created. Further research is needed to obtain a deeper understanding of the mechanisms that help to improve tourism activities. 


\section{ACKNOWLEDGMENT}

The paper is prepared within the project III 46006 Sustainable agriculture and rural development in the function of accomplishing strategic objectives of the Republic of Serbia in the Danube region, financed by the Ministry of Education, Science and Technological Development of the Republic of Serbia.

\section{REFERENCES}

Baćac. R., (2011): Priručnik za bavljenje seoskim turizmom, Tiskara Zelina d.d., Zagreb.

Bošković Tatjana (2010): Turizam kao faktor privrednog razvoja.

Bosnić Irena, (2011): Agroturizam u globalizacijskim procesima, Stručni rad, Vol 2., br. 3.

Bramwell, B., (1994): Rural tourism and sustainable rural tourism, Journal of Sustainable Tourism $2(1-2)$.

Cvijanović, D., Vlahović, B., \& Milić, D. (2007). Employment possibilities in rural areas of Serbia the factor of production increment and food export. Economics of Agriculture, 54(1), 61-72.

Demonja, D., Ružić, P., (2010): Ruralni turizam u hrvatskoj s hrvatskim primjerima dobre prakse i europskim iskustvima. Samobor: Meridijani.

Đenadić, M., Muhi, B., \& Jovanović, D. V. (2016). Rural tourism-Serbia's missed chance. Economics of Agriculture, 63(2), 515-529.

Erdeji, I., Gagić, S., Jovičić, A., \& Medić, S. (2013). Development of rural tourism in Serbia. J. Settel. Spat. Plann, 4(2), 309-315.

Gašić, M. \& Ivanović, V., (2018): Rural tourism in Serbia and impact on economic and social development, 3rd International Thematic Monograph - Thematic Proceedings: Modern Management Tools and Economy of Tourism Sector in Present Era.

Gajić, T., (2010). Tourism in the Intensification of the Economic Development of Receptive and Emitting Areas - An Example of the South Backa District. Industry, 38 (3), Belgrade

Halloran, M. O., (2000): Rural tourism in Australia: the visitor's perspective, Australia. Bureau of Tourism Research, Canberra.

Hay, G. J., \& Castilla, G., (2006): Object-based image analysis: strengths, weaknesses, opportunities and threats (SWOT). In Proc. 1st Int. Conf. OBIA.

Horwath Consulting Zagreb (2009): Strategija razvoja ruralnog turizma Splitsko dalmatinske Županije. Split: Turisticka zajednica Splitsko-dalmatinske Županije.

https://www.turizamiputovanja.com/aktivnosti-turista-seoskom-turizmu/ (Accessed: October 2019.)

Jelinčić D. A., (2007): Agroturizam u Europskom kontekstu, Pregledni rad, 348.48 (4-22), Vol. 19.

Kastenholz, E., Davis, D, Paul, G., (1999): Segmenting tourism in rural areas; The case of north and central Portugal, Journal of Travel Research, Boulder.

Kesar, O., (2013): Seoski turizam, Sveučilište u Zagrebu, Ekonomski fakultet, Zagreb.

Kotler, P. and Keller, K., (2006): Marketing Management. 12th Edition, Prentice Hall, Upper Saddle River.

Krajnović, A., Čičin-Šain, D., Predovan, M., (2011): Strateško upravljanje razvojem ruralnog turizma - problemi i smjernice. Oeconomica Jadertina, Sveučilište u Zadru, Odjel za ekonomiju, Zadar, Hrvatska.

„Master plan održivog razvoja ruralnog turizma u Srbiji“ 2011 https://futurehospitalityleaders. files.wordpress.com/2012/11/master-plan-odrzivog-razvoja-ruralnog-turizma-u-srbiji.pdf (Accessed: October 2019.)

Maričić, B., (2011): Ponašanje potrošača (ISBN 978-86-403-1084-0). CID, Ekonomski fakultet, Beograd. 
Midllton V., Clarke J.R., (1993): Marketing in Travel and Tourism. Butterworth Heinemann, Oxford. Milovanović Jelena, Đorđević Milošević Suzana, (2012): Održivi turizam u funkciji ruralnog razvoja. Mala poljoprivredna gazdinstva i ruralni turizam u Srbiji, Univerzitet Singidunum Beograd.

Muhi, B., (2013): Ruralni turizam kao komponenta integralnog i održivog razvoja sela u Vojvodini, Zbornik matice srpske za društvene nauke, Novi Sad.

Petković, G., Zečević, B., Pindžo, R., (2011): Turizam kao deo nacionalne ekonomije. Ekonomika preduzeća, vol. 59, br. 1-2.

Priručnik za ruralni turizam https://vojvodinaonline.com/media/2015/12/Ruralni-vodic-2015-Latinical.pdf (Accessed: October 2019.)

Rabotić, B., (2012.): Selektivni oblici turizma, Visoka turistička škola strukovnih studija.

Ružić, P., (2009): Ruralni turizam, Istitut za poljoprivredu i turizam, Poreč.

Senečić J., Grgona J., (2006.): Marketing menadžment u turizmu, Mikrorad, Zagreb.

Sirgy, M.J., (2001): Handbook of Quality-Of-Life research: An ethical marketing perspective. Dordrecht: Kluwer Academic Publisher.

Smith, M. MacLeod, N. Hart, M., (2010): Key Concepts in Tourist Studies, Sage Publications Ltd.

Swarbrooke, J., (1996): Towards the Development of Sustainable Rural Tourism in Eastern Europe, In G. Richards (ed.): Tourism in Central and Eastern Europe: Educating for Quality, ATLAS, Tilburg.

Todorović, M., Štetić, S., (2009): Ruralni turizam. Univerzitet u Beogradu, Geografski fakultet.

Unković, S., Zečević B., (2006): Ekonomika turizma, Ekonomski fakultet Beograd.

Vlahović, B., Potrebić, V., \& Jeločnik, M. (2012). Preferences of wine consumers on Serbian market. Economics of Agriculture, 59(1), 37-49.

Vlahović, B., Puškarić, A., \& Kuzman, B. (2015). Marketing vina i vinski turizam Vojvodine, p. 158 Priručnik za proizvođače vina. Vlada Vojvodine, Sekretarijat za poljoprivredu, vodoprivredu i šumarstvo, Novi Sad. ISBN 978-86-85855-18-4.

Vlahović, B., \& Užar, D. (2017). Wine purchase preferences of young consumers." Agroekonomika 75, p.63-74

Žanko, Ivana (2013): Stavovi i preferencija turista prema agroturizmu s naglaskom na agroturizam u Hrvatskoj, Sveučilište u Splitu, Ekonomski Fakultet, Split. 